\title{
Produktiivinen mimesis
}

Miten sukupuoli piirtyy säveltäjän materiaaliin

- Säveltäjä, pedagogi, MuM RiikkaTalvitie (riikka.talvitie@uniarts.fi)valmistelee taiteellista tohtorintutkintoaan säveltäjän työnkuvan muutoksesta Taideyliopiston Sibelius-Akatemian DocMus-tohtorikoulussa. Talvitie aloittaa syksyllä 2021 Taideyliopiston sävellyksen lehtorin määräaikaisessa tehtävässä. 


\title{
Produktivinen mimesis
}

\author{
Miten sukupuoli piirtyy säveltäjän materiaaliin
}

\section{Riikka Talvitie}

Klassisen musiikin säveltäjien sukupuolten tasa-arvon voisi tällä hetkellä kiteyttää seuraavasti: länsimaisen taidemusiikin kaanon muodostuu ensisijaisesti miessäveltäjistä. Tilastollisesti katsottuna miesten säveltämää musiikkia esitetään enemmän, mikä johtuu suurimmaksi osaksi siitä, että kuolleiden säveltäjien osuus ohjelmistosta on suuri. Nykysäveltäjistä edelleen valtaosa on miehiä, tosin epäsuhta on vähitellen tasaantumassa. Naisilla ja muunsukupuolisilla henkilöillä on yhdenvertaiset oikeudet säveltää ja opiskella säveltämistä. Kuitenkin nuorista miesoletetut pyrkivät aktiivisemmin sävellyksen ammattiopintoihin, mihin saattaa vaikuttaa naispuolisten esikuvien puute. Musiikkiopistoissa lapsille ja nuorille tarjotaan sävellysopetusta tasavertaisesti. (Ks. esim. Partti 2019.)

On helppo olla samaa mieltä siitä, että yhdenvertaisuutta tulisi edistää, mutta vaikeampi kysymys on, mitä asialle voi käytännössä tehdä. Historiallisesti tasa-arvoa on edistetty sekä yhteiskunnallisen aktivismin, poliittisten päätösten, tutkimuksellisten intressien että pedagogisten toimintatapojen avulla. Klassisen musiikin säveltämisen osalta nämä keinot ovat purreet muita taidealoja hitaammin.

Feminismin ensimmäisessä aallossa 1800-1900-lukujen taitteessa taisteltiin naisten äänioikeuden puolesta. Tuota aikaa kuvaa mainiosti tarina brittiläisestä suffragetti-säveltäjästä Ethel Smythistä (1858-1944), joka johti ystäviensä laulua hammasharjallaan sellinsä kaltereiden läpi Hollowayn vankilassa. Smyth oli räväkkä poikkeus säveltäjien joukossa. Yhdysvalloissa 1960-luvulta käynnistynyttä feminismin toista aaltoa voi seurata mielenkiintoisesta Mrs. America -TV-sarjasta, jossa naiset käyvät taistoon naisia vastaan. Feministit halusivat rikkoa lasikattoja, kun taas kotiäidit katsoivat tulleensa uhatuiksi.

Samoihin aikoihin luotiin pohjaa myös feministiselle taiteelle. Naisille, jotka tuohon asti olivat olleet pikemminkin taiteen kohteena, haluttiin antaa yhdenvertainen asema itse taiteilijoina. Naisten asema tosin näyttäytyi hyvin erilaisena eri taiteen aloilla. Samaan aikaan kun perfor- 
manssitaiteilija Yoko Ono vuonna 1964 herätti keskustelua teoksellaan Cut Piece, jossa hän tarjosi yleisön jäsenille saksia, jotta nämä voisivat leikata paloja hänen vaatteistaan, ei nykymusiikin arvostetuimmalla estradilla Darmstadtissa esitetty kenenkään naispuolisen säveltäjän musiikkia. ${ }^{1}$ Ei tämä toinenkaan aalto heilauttanut länsimaisen taidemusiikin kaanonia mitenkään laajemmin.

Tiedemaailmassa sukupuolentutkimus, alun perin naistutkimukseksi kutsuttu monialainen akateeminen tutkimusala, tuli yliopistoihin Yhdysvalloissa 1960-70-lukujen taitteessa. Sukupuolentutkimus on ytimeltään kriittistä ja emansipatorista, mikä tarkoittaa, että tutkimuksessa keskitytään tutkittavan ilmiön taustalla piileviin tiedostamattomiin valtarakenteisiin ja sosiaalisiin suhteisiin. Tämä Frankfurtin koulukunnan viitoittama kriittinen tiedonintressi kurottaa kohti muutosta.

Yksi sukupuolentutkimuksen perusteoksista, Simone de Beauvoirin Toinen sukupuoli ilmestyi ranskaksi jo vuonna 1949. Siinä Beauvoir pohtii naissukupuolen alisteista ja toissijaista asemaa mieheen nähden (de Beauvoir 2020). Vaikka kirja päätyikin katolisen kirkon kiellettyjen kirjojen luetteloon, toimi se lähtölaukauksena feministiselle keskustelulle. Tutkimusalan muotoutumiseen ovat sittemmin vaikuttaneet monet teoreettiset lähestymistavat, kuten esimerkiksi 1970-80-luvuilla kehittynyt psykoanalyysiin ja kieleen keskittynyt ranskalaisen feminismin suuntaus, jota edustaa Hélène Cixous'n ja Julia Kristevan lisäksi tässä kirjoituksessa jäljempänä esiin nouseva Luce Irigaray.

1990-luvulla käynnistynyt feminismin kolmas aalto pohjaa monelta osin ranskalaisen feminismin teoriaan. Ajan hengen voi tiivistää yhdysvaltalaisen filosofin Judith Butlerin (1990) toteamaan: sukupuoli on tekemistä. Butlerin mukaan sukupuoli tuotetaan jatkuvasti uudestaan erilaisia sosiaalisia käytäntöjä ja normeja toistamalla. Sukupuoli sisäistetään eleitä ja tekoja jäljittelemällä. Vaikka taidemusiikin kaanon ei edelleenkään saanut pahempia kolhuja musiikkialan instituutioissa, sai tämä kolmas aalto sentään musiikkitieteilijät aktivoitumaan: Susan McClaryn teos Feminine Endings julkaistiin vuonna 1991 ja Marcia Citronin Gender and the Musical Canon 1993. Myös Lydia Goehrin merkittävä kannanotto musiikkiteoksen käsitteeseen, The Imaginary Museum of Musical Works ilmestyi 1992. Mutta sen sijaan että feministisen musiikintutkimuksen herääminen olisi käynnistänyt merkittävää liikehdintää sävellysrintamalla, se pikemminkin syvensi tieteen ja taiteen välistä kuilua. https://griddarmstadt.files.wordpress.com/2016/08/grid_gender_research_in_darm-
stadt.pdf (tark. 19.6.2021). 
Kaikissa näissä suuntauksissa päämääränä on ollut muuttaa maailmaa aktiivisesti, ei vain todeta sen olevan epätasa-arvoinen. Vaikka sosiaaliset ja poliittiset tilanteet eri yhteiskunnissa vaihtelevat, pyrkimykset muutokseen ovat samankaltaisia. Joskus ratkaisun avain piilee järjestelmissä ja niiden purkaminen on hidasta, vaikka poliittista tahtoa löytyisikin. Joskus taas anarkistinen vallankumous on ainoa vaihtoehto.

\section{Säveltäminen on vain jäljittelyä}

Millainen kumouksellinen toiminta tuottaisi tulosta nykymusiikin alalla? Säveltäminen tapahtuu tietyssä kulttuurisessa kontekstissa, mutta sen erityispiirteenä on toimia musiikillisen materiaalin ja muodon kautta. Hyvin abstraktisti siis. Muutokseen tarvitaan näin ollen keinoja, jotka ulottuvat musiikillisen materiaalin tasolle, siihen maailmaan, jossa säveltäjät viettävät suurimman osan ajastaan. Tehokkainta toki olisi, jos muutos lähtisi sisältäpäin, säveltäjien toimesta säveltämällä.

Edellä mainittujen feminististen teorioiden joukosta olen löytänyt yhden, jota pidän säveltäjän näkökulmasta erityisen kiinnostavana: se on filosofi, kielitieteilijä ja psykoanalyytikko Luce Irigarayn ajatus produktiivisesta mimesiksestä, jonka avulla hän tarkastelee naisen suhdetta filosofian kaanoniin. ${ }^{2}$ Esimerkin valossa voidaan vastaavasti pohtia, mikä on elävän (nais)säveltäjän ja länsimaisen taidemusiikin kaanonin välinen suhde.

Irigaray väittää, että vain jäljittely tarjoaa naisille pääsyn vallitsevaan diskurssiin. Irigaraylle mimesis on prosessi ja kriittinen työkalu, jonka avulla hän kommentoi filosofian historiaa ja maskuliinisen kaanonin klassikoiksi muodostuneita tekstejä. Esimerkiksi väitöskirjassaan Speculum de l'autre femme (1974) hän lukee ironisesti muun muassa Platonia ja Freudin naiseutta käsitteleviä tekstejä. Hänen mukaansa filosofian diskurssissa naisella ei ole ääntä, vaan naisen kirjoitus on aina miehen heijastusta. Mimeettistä asemaa muuntamalla hän kyseenalaistaa absoluuttisena pidetyn filosofian subjektin ja samalla antaa naissubjektille mahdollisuuden. (Ks. Lehtinen 2014, 13-21; Sivenius 1996, 7-8.)

2 Kreikankielinen sana mimesis voidaan suomen kielessä kääntää jäljittelyksi, jolloin toiminta viittaa imitaatioon, matkimiseen tai kopioimiseen, ja toisaalta esittämiseksi tai edustamiseksi, jolloin käsite liittyy ajatukseen representaatiosta (Mikkonen ja Salminen 2017, 4). 
Irigarayn mukaan mimesis voi olla reproduktiivista ja kopioivaa tai produktiivista ja luovaa. Reproduktiivinen mimesis tarkoittaa perinteisten tulkintojen ja sukupuoliasetelmien toistamista samanlaisina kuin olemme valtakulttuurissa tottuneet. (Lehtinen 2014, 25.) Produktiivinen mimesis sen sijaan tarjoaa tietoisen ja aktiivisen tavan hyödyntää jäljittelyn ja esittämisen mahdollisuuksia. Produktiivinen mimesis on tietoinen strategia, jonka avulla Irigaray käy keskustelua filosofisen diskurssin ehdoista. Keinoina hän käyttää muun muassa ironiaa, parodiaa, toistoa ja tavallisesta poikkeavaa kontekstualisointia. (Ibid., 39-43.)

Irigaray on tutkimuksissaan keskittynyt sukupuolen ilmenemiseen kirjoitetussa ja puhutussa kielessä, kun taas Butler on käsitellyt sukupuolen jäljittelyä laajemmin sosiokulttuurisena ilmiönä. Sukupuolen parodiointi esimerkiksi drag-kulttuurissa osoittaa häilyvän rajan "imitaation" ja "alkuperäisen" välillä. Butler itse asiassa osoittaa, ettei mitään sukupuolen alkuperää tai yhtenäistä identiteettiä ole. (Butler 1990, 137-138.) Tämä ajatus avaa laajan pohdinnan myös säveltäjän identiteetin näkökulmasta.

Säveltämisen suhde mimesikseen jää usein säveltäjiltä huomiotta. Jokainen säveltäjä kuvittelee olevansa ainutlaatuinen, vaikka itse asiassa jo säveltämisen oppiminen tapahtuu monelta osin imitoimalla. ${ }^{3}$ Säveltäjät ikään kuin asettuvat taidemusiikin historian jatkumoon jäljittelemällä niin kuolleita kuin eläviä kollegoitaan. Vaikka musiikillisen materiaalin jäljittely vaikuttaa tekona neutraalilta, se sisältää kuitenkin mahdollisuuden kriittiseen luentaan, joka ei ole vain viatonta toistoa vaan voi sisältää kommentointia, uudelleenkirjoitusta ja totutun näkökulman hylkäämistä.

Irigaray vertaa filosofista diskurssia kankaaseen, tekstuuriin, jossa käsitteet ja käsitteelliset rakenteet muotoutuvat, artikuloituvat sekä sedimentoituvat puheen ja kirjoituksen toistuvissa tapahtumissa. Myös musiikin historia voidaan nähdä samanlaisen materiaalin sedimentaationa, johon on vuosien varrella kerääntynyt kaikenlaista "arvopohjaa", joka ei ole puhtaasti esteettistä. Irigaraylle filosofinen diskurssi ei ole pysyvää, vaan se syntyy jatkuvassa vuoropuhelussa eletyn ja koetun todellisuuden kanssa. (Ks. Lehtinen 2014, 24.)

Vastaavasti nykymusiikin diskurssissa säveltäjät, miehet, naiset ja muut, käyvät vuoropuhelua nykyhetken kanssa omalla tavallaan, mutta onko se samassa mielessä produktiivista kuin Irigaray tarkoittaa. Irigaraylle produktiivinen mimesis vaatii naisen roolin tiedostamista ja jopa

3 Uutuudesta ja originaalisuudesta nimenomaan maskuliinisena kanonisoitumiseen liittyvänä arvona ks. Citron 2000 [1993], 69-71. 
sen tahallista omaksumista, jotta tuosta asemasta voi astua syrjään ja samalla horjuttaa vallitsevaa diskurssia. Tässä kohden filosofian ja nykymusiikin diskurssien vertaaminen toisiinsa muuttuu hankalammaksi, koska musiikista on vaikeampi määritellä tekijän sukupuoliasemaa. Säveltäjät voivat kuitenkin rakenteellisesti pyrkiä toimimaan toisin. Esimerkki säveltäjästä, joka on pseudonyymien ja fiktiivisten henkilöhahmojen avulla hämmentänyt nykymusiikin kenttää, on irlantilainen säveltäjä Jennifer Walshe. Hänen sarkastiseen huumoriinsa voi tutustua projekteissa Grúpat ${ }^{4}$ ja Aisteach: The Avant Garde Archive of Ireland. ${ }^{5}$ Aisteach käsittelee sitä, kuka saa kuratoida - "kuka saa valita, mikä taiteellinen kaanon on ja miksi”, Walshe kysyy. ${ }^{6}$ Ehkä säveltäjien - ja säveltäjäyhteisön - itseironiaa voidaankin pitää jonkinlaisena ensimmäisenä ehtona ja välttämättömyytenä taidemusiikin kaanonin purkamisprosessissa.

Feminismin erilaiset ilmenemismuodot, akateemiset versus aktivistiset, ovat monessa kohdin törmänneet toisiinsa. Eri näkökulmista asetetut tavoitteet ovat vaikuttaneet miltei ristiriitaisilta. Feministiaktivistit ovat kritisoineet akateemista feminististä teoriaa "miehisten valtapelien pelaamisesta, osallisuudesta ja avunannosta samoihin miehisen vallankäytön muotoihin, joita feministien tulisi yrittää päihittää” (Grosz 2013, 61). Feministinen filosofia taas on pyrkinyt säilyttämään tieteessä totutun ankaruuden ja toimimaan tradition vaatimalla tavalla. Erityisesti kiista essentialismista, pyrkimyksestä asettaa naiselle jokin pysyvä ja yhtenäinen olemus, on jakanut mielipiteitä. (Grosz 2013.)

Samanlainen törmäys on helposti kuviteltavissa myös klassisen musiikin maailmaan. Naissäveltäjien ura ja meritoituminen tapahtuu samojen mekanismien mukaisesti kuin alalla on aina toimittu. Naisten osallisuuden myötä ei ole syntynyt uudenlaista toimintakulttuuria tai perustavasti toisenlaisia olemisen tapoja. Saavutettua asemaa ei tohdi murentaa liiallisella poliittisella aktivismilla ja rakenteiden uhmaamisella. Samalla kun länsimaisen taidemusiikin kaanoniin tarvitaan lasikattojen murtajia ja esikuvia, kanonisoinnin vaarana on, että sinne hyväksytään vain tietynlaisia (nais)säveltäjiä. (Vrt. McClary 1991, 18-19; Citron 2000 [1993], erit. 156-164.)

Tosielämässä naisroolit ovat huomattavan moninaiset, vaikka emme juurikaan puhu niistä julkisesti. Vähitellen nykymusiikkiyhteisössä on virinnyt keskustelua äitiydestä ja siitä, miten perhe-elämän ja säveltä-

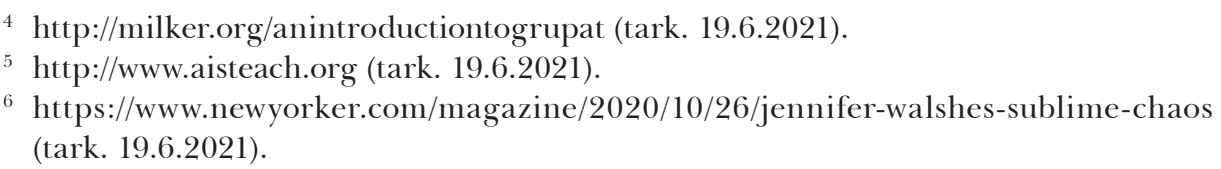


misen voi käytännössä yhdistää. ${ }^{7}$ Ehkä eteerisen runotytön hahmo, joka lempeästi solahtaa äitiyden huuruihin ja vanhenee sivistyneesti, onkin rooleista sallituin. Ydinperheen äitien lisäksi (nais)säveltäjistä löytyy vapaaehtoisesti tai tahtomattaan lapsettomia, uusperheen äitejä ja yksinhuoltajia, homoseksuaaleja ja transihmisiä, muista ominaisuuksista ja taustoista puhumattakaan.

Tämä moninaisuuden kirjo johdattaa meidät mimesiksen toiseen ulottuvuuteen, nimittäin esittämiseen ja edustamiseen eli representaatioon. Tällöin itse jäljittelyä merkittävämpiä kysymyksiä ovat, ketä jäljitellään ja kenellä on oikeus jäljitellä. Kuten Leena-Maija Rossi (2010, 261) toteaa, representaatio on politiikkaa sekä samalla politisoivaa tekemistä. Säveltämisen motiivi kytkeytyy yhä konservatiivisesti yksilön äänen esille tuomiseen. Jos päivitämme Irigarayn ajatuksen tällä hetkellä käytyyn keskusteluun intersektionaalisuudesta ja representaatiosta, produktiivisuus voisi yksilön toiminnan ja uran korostamisen sijaan tarkoittaa yhteisöllistä ja institutionaalista tavoitetta laajemmasta edustavuudesta ja yhdenvertaisuudesta. Kenenkään yksittäisen säveltäjän ilmaisu ei riitä, vaan diskurssin vakiinnuttamiseksi tarvitaan useiden yksittäisten säveltäjien ilmaisua suhteessa toisiinsa (vrt. Lehtinen 2014, 84-85). Tämä keskustelu on vasta käynnistymässä klassisen musiikin kentällä.

Radikaalisti mutta samalla pedagogisesti väitän, että säveltäminen on vain jäljittelyä. Tämä tarkoittaa sitä, että säveltäjäidentiteettien moninaisuus alkaa ilmetä vasta lukuisten toistojen seurauksena edellyttäen, että nämä toistot ovat tiedostettuja, kriittisiä ja strategisia. Ehdotukseni produktiivisesta mimesiksestä säveltäjän menetelmällisenä työtapana vertautuu emansipatorisen tutkimuksen tavoitteisiin muuttaa yleisesti hyväksyttyä tapaa kirjoittaa. Tietoisen, kommentoivan jäljittelyn avulla on mahdollista yhtäältä purkaa alan sisäisiä ääneen lausumattomia arvoja, jotka salakavalasti sulkevat pois "vääränlaisen ja epäkelvon" toiminnan, ja toisaalta laajentaa nykymusiikin osallisuutta yhteiskunnan eri osa-alueilla. $^{8}$

Olennainen kysymys on, miten tulevia säveltäjäsukupolvia kasvatetaan. Sekä kriittisen että feministisen pedagogiikan taustalta löytyy vas-

7 Ks. esim. https://nmbx.newmusicusa.org/composing-and-motherhood https://www. epressi.com/tiedotteet/sosiaaliset-kysymykset/saveltaja-outi-tarkiainen-on-valittuvuoden-naiseksir.html (tark. 19.6.2021).

8 Olen kokeillut parodista sitaattitekniikkaa laajemmin radio-oopperassa Kylmän maan kuningatar (2017), jonka sävelsin puhtaasti kansallishymnisitaattien pohjalta tarkoituksenani käsitellä nationalismin teemaa. Kutsun työtapaa aineistolähtöiseksi säveltämiseksi. 
taava tavoite yhdenvertaisuuden edistämisestä. Feministisen pedagogiikan uranuurtajan, yhdysvaltalaisen bell hooksin mukaan opiskelun tulisi kannustaa nuoria aktiivisesti muuttamaan vallitsevaa yhteiskuntajärjestystä ja kulttuurisia toimintatapoja sen sijaan, että he vain sopeutuvat eriarvoisuutta ylläpitäviin rakenteisiin (Ojala 2018, 24).

Musiikinhistorian tutkimus on osoittanut, että monet naisten säveltämät teokset ovat vain kadonneet ohjelmistosta. Emme pysty tarkkaan osoittamaan, mitkä ominaisuudet joko säveltäjissä tai teoksissa ovat aiheuttaneet tämän poispyyhkiytymisen. Emme myöskään voi varmuudella luvata, ettei vastaava mekanismi vaikuta edelleen syrjivästi konserttien ja festivaalien ohjelmistoa valittaessa. Meidän tulee kollektiivisesti olla hereillä, ettei juuri tuo poissuljettu "vääränlainen ja epäkelpo" pidä sisällään sitä toiseutta, jota musiikkialan tasa-arvokeskusteluissa peräänkuulutamme. Säveltäminen koostuu lukuisista työvaiheista ja esteettisistä yksityiskohdista. Identiteettien moninaisuus, joka voi hyvinkin olla piiloutuneena näihin säveltäjän jokapäiväisiin arkisiin valintoihin, on mahdollista saada kuuluville toistamalla uudenlaista säveltämisen tapaa määrätietoisesti ja strategisesti uudestaan ja yhä uudestaan.

\section{Lähteet}

Butler, Judith. 1990. Gender Trouble. Feminism, and the Subversion of Identity. New York, NY: Routledge.

Citron, Marcia. 2000 [1993]. Gender and the Musical Canon. Cambridge: Cambridge University Press.

De Beauvoir, Simone. 2020. Toinen sukupuoli [Le Deuxième sexe, 1949], suom. I. Koskinen, H. Lukkari ja E. Ruonakoski. Helsinki: Tammi.

Goehr, Lydia. 1992. The Imaginary Museum of Musical Works: An Essay in the Philosophy of Music. Oxford: Clarendon Press.

Grosz, Elizabeth. 2013. "Sukupuoliero ja essentialismin ongelma”. ["Sexual Difference and the Problem of Essentialism", 1989.] Suom. Elina Halttunen-Riikonen. niin E゚ näin 3/2013: 61-72. Tark. 18.6.2021. https://netn.fi/sites/www.netn.fi/files/netn133$12 . \mathrm{pdf}$

Irigaray, Luce. 1974. Speculum de l'autre femme. Paris: Minuit.

Lehtinen, Virpi, 2014. Luce Irigaray's Phenomenology of Feminine Being. New York, NY: SUNY Press.

McClary, Susan. 1991. Feminine Endings: Music, Gender, and Sexuality. Minneapolis, MN: University of Minnesota Press.

Mikkonen, Jukka ja Antti Salminen. 2017. Johdanto teoksessa Mimesis: filosofia, taide, yhteiskunta, toim. J. Mikkonen ja A. Salminen, 4-8. Jyväskylä: Jyväskylän yliopisto. Tark. 18.6.2021. https://www.jyu.fi/hytk/fi/laitokset/yfi/tutkimus/sophi/126-150/sophi136 
Ojala, Hanna, 2018. "bell hooks: Feministisen pedagogiikan uranuurtaja”. Teoksessa Feministisen pedagogiikan ABC - opas ohjaajille ja opettajille, toim. Anu Laukkanen et al., 23-25. Tampere: Vastapaino

Partti, Heidi. 2019. "Yhdenvertaisesti säveltäen -hanke pyrkii edistämään tasa-arvoisia osallistumismahdollisuuksia". Musiikkikasvatus 1 \& 2 (22): 174-178.

Rossi, Leena-Maija. 2010. ”Esityksiä, edustamista ja eroja. Representaatio on politiikkaa”. Teoksessa Representaatio. Tiedon kivijalasta tiedon työkaluksi, toim. Tarja Knuuttila ja Aki Petteri Lehtinen, 261-275. Helsinki: Gaudeamus.

Sivenius, Pia. 1996. "Sukupuolieron etiikasta”. Esipuhe Luce Irigarayn teoksessa Sukupuolieron etiikka [Éthique de la différence sexuelle, 1984], suom. Pia Sivenius, 5-16. Helsinki: Gaudeamus. 